\title{
Food and the Everyday in Spain: Immigration and Culinary Renovation Enric Bou
}

\begin{abstract}
This article presents a reflection on two interrelated topics: the modification of eating habits in Spain, a key aspect of everyday life, through the presence of an enormous migration movement that started in the 1990's, and the intervention of migrant workers in the food chain, particularly in rural areas with heavy agriculture development such as Lleida and surrounding towns. It will provide a reading of two recent texts (a film and a book) that deal with immigration and food issues. Both El próximo Oriente by Fernando Colomo, and La pell de la frontera by Francesc Serés offer enough evidence about the transformation through food of contemporary Spain. In these texts food is a powerful weapon of social and physical control, and encapsulates some of the many adjustments that have occurred in Spanish society. The kitchen, at home or at the restaurant, as a private or as a public space, becomes a setting to display the fine line between the familiar and the uncanny, between a domestic thus safe and a hostile environment.
\end{abstract}

Key Words: Food Studies, Immigration, Everyday Life

\section{tweetable abstract}

The modification of eating habits in Spain, through migration as seen in Colomo's El próximo Oriente by, and Serés' La pell de la frontera.

In the year 2000, fiction writer and culinary expert Manuel Vazquez Montalbán published a series of articles under the title 'De Portbou a Hendaya. La vuelta a la cazuela de España', where he discussed Spain's culinary traditions at the turn of the century without ever mentioning the new Spain that was changing under his eyes, through the presence of massive immigration. As a result, there is a transformed society with different tastes and experimenting with foreign cooking traditions that Vázquez Montalbán failed to picture. This is even more remarkable in the case of an author that always was very attentive to analyzing social aspects of reality. ${ }^{1}$ Perhaps it was too early to detect the paradox addressed by Ray in The Ethnic Restaurateur, that although the foreign-born have numerically

\footnotetext{
${ }^{1}$ Manuel Vázquez Montalbán published De Portbou a Hendaya. La vuelta a la cazuela de España as a series of articles in El país, in August 2000. It would unfair to say that, being the son of immigrants, he did not pay attention to the transformation of Spain in many of his articles or novels, but maybe because it was too early and the effects were not still visible in restaurants, he did not ruminate on the food effects of such a social makeover. This is confirmed in personal communications from two MVM experts (to whom I am most thankful), José F. Colmeiro and José Saval. Araceli Masteson-Algar's Ecuadorians in Madrid: Migrants Place in Urban History (Palgrave McMillan, 2016), 3-5, offers an up-to-date review of Spain's transformation.
} 
dominated the feeding occupations in the developed world cities, their presence in the culinary field and their own perspective on the transaction of taste are lacking in the literature that deals with taste and culture-making. ${ }^{2}$ French novelist Jean-Claude Izzo has purposely incorporated in his novels this reality in the city of Marseille. Since the 1990's, African and Latin American immigration to Spain has dramatically changed a once homogenous society. The impact of this migration has created new spaces of communication and coexistence where food plays an important role and in turn is a major actor and has forced a significant social transformation. ${ }^{3}$

Food had played a significant part in Spain's history during the scarcity of the years of war and dictatorship. This produced discourses about the need for sacrifice and duty of the citizen affecting both the public and private spheres. The situation changed radically in the sixties, the desarrollo years, and even more with the successful application for membership in the European Union. Successful Spanish cooks and flashy restaurants have been a part of the so called Marca España's revival, and they have swamped the land with TV shows, culinary books, special sections in newspapers, blogs, etc., and have made Spanish cuisine subject of international attention. ${ }^{4}$ Ferran Adrià's participation in Documenta 12 in the year 2007 was a remarkable feat. Consequently, recent immigration waves have created a focus on food and what it represents as an engine of social change. Dining practices, traditional foods, ingredients and new products begin to form part of a new horizon of everyday expectations. ${ }^{5}$

${ }^{2}$ Krishnendu Ray, The Ethnic Restaurateur (New York: Bloomsbury Academic, 2016), 1.

3 There is very little research on this aspect. There are some sociological studies on the case of Latin American immigrants to Spain: R. Romo, and J. M. Gil, 'Ethnic identity and dietary habits among Hispanic immigrants in Spain" British Food Journal 114, 2 (2012), 206-223.

4 At the time of the 1992 Olympics many magazines devoted special issues to Spanish food, thus starting a fade for tapas restaurants.

${ }^{5}$ There are very few studies devoted to the study of everyday life in Spain. Interestingly enough there have been many more studies devoted to the study of the everyday in Modern ages, Encarnación Medina Arjona, Paz Gómez Moreno, eds. Escritura y vida cotidiana de las mujeres de los siglos XVI y XVII (Madrid: Ediciones Alfar 2015). 'Post Scriptum: A Digital Archive of Ordinary Writings' is a project that aims to collect and publish Portuguese and Spanish private letters written during the Modern Ages. These are epistolary unpublished documents, written by authors from different social backgrounds. These documents survived by chance 
In this article I will present a reflection on two interrelated topics: the modification of eating habits in Spain, a key aspect of everyday life, through the presence of an enormous migration movement that started in the 1990's, and the intervention of migrant workers in the food chain, particularly in rural areas with heavy agriculture development such as Lleida and surrounding towns. I will provide a reading of two recent texts, a film and a book, that deal with immigration and food issues. Both El próximo Oriente (2006) by Fernando Colomo, and La pell de la frontera (2012) by

Francesc Serés offer significant evidence about the transformation through food of contemporary Spain. In these texts food is a powerful weapon of social and physical control, and encapsulates some of the many adjustments that have occurred in Spanish society. The kitchen, at home or at the restaurant, as a private or as a public space, becomes a setting to display the fine line between the familiar and the uncanny, between a domestic thus safe and a hostile environment. Louise Edwards has explained how in the context of immigration and changing food ways, new foodstuffs or food culture can be both exciting and threatening. ${ }^{6}$ It could be read as a variant to the omnivore's paradox: the ability of human beeings to adapt mixed to danger and curiosity. Immigrant's food

because the Inquisition and the civil courts used them as criminal evidence. These textual resources treat everyday issues related to past centuries. Everyday life has also been addressed from a philosophical point of view, Marcelino Agís Villaverde 'Pensar la vida cotiadiana', in Marcelino Agís Villaverde, Carlos Baliñas Fernández, eds. Pensar la vida cotidiana. Encuentros Internacionales de Filosofía en el Camino de Santiago = Encontros Internacionais de Filosofía no Camiño de Santiago. Santiago de Compostela. Santiago de Compostela: Universidade de Santiago de Compostela, Servizo de Publicacións e Intercambio Científico, 2001, 11-24). Historians have paid attention to the renewal in everyday life after Franco's dictatorship, Mario Diaz Barrado, La España democrática (Madrid: Sintesis, 2014). This last author's point is that culture and daily life have been radically altered in the last quarter of the twentieth century by the combined effect of technological change and the impact of mass media. Díaz Barrado pays attention to what has been razed and the new habits that set the course into the twenty-first century. Rafael Abella's La vida cotidiana bajo el régimen de Franco (Barcelona: Argos Vergara, 1985), or Agustín Sánchez Vidal's Sol y sombra. De cómo los españoles se apearon de las mayúsculas de la bistoria dotándose de vida cotidiana (Barcelona: Planeta, 1990) are two of the few examples available, though none of them makes a consistent approach, in defining from a theoretical perspective what everyday life is. Both books tackle the issue in a very different way. The latter tries to solve the riddle of several coincidences such as the simultaneous arrival in Spain of The Beatles' Sergeant Pepper's record and the use of credit cards. Sánchez Vidal is willing to emphasize the consequences brought about by these and other minor events, always giving them preference over the great historical event, the most seemingly nondescript fact, with the aim of reaching a convincing interpretive synthesis of the past.

${ }^{6}$ Louise Edwards, Stefano Occhipinti \& Simon Ryan, 'Food and Immigration: The indigestion trope contests the sophistication narrative' Journal of Intercultural Studies 21.3 (2000), 297-308. 
allows travelling without using passports, a safe detour from daily routines without the dangers of Moctezuma's revenge. Some unnoticed aspects of the food industry are denounced in Serés's book and contain innovative portrayals of immigration and of the transformation of the country as a whole, always seen from a very intimate perspective.

\section{Assimilation through love and food}

Narratives and films on immigration to Spain have focused mostly on the transition between the home country and their destination, what according to Linhard we could call the shipwreck, that in many ways unleashes the post-colonial specters. ${ }^{7}$ Here I focus on one example that pays attention to the aftermath of this transition, in particular the clash between food cultures once the shipwreck has been somehow assimilated. ${ }^{8}$

The opening credits of Fernando Colomo's film Elpróximo Oriente conclude with a close-in on two elements that are essential to the development of the plot and its main threads. A young man (shortly after we will find out that he is Caín, one of the main characters) is cutting pieces of meat in the shop where he works, and a protest sign written in many languages is shown hanging from a balcony. It reads: 'Papeles para todos'. Before this we have seen glimpses of many multiethnic stores and situations that point to the changing nature of a society, most remarkably foreign food and publicity for cheap calls to foreign countries, etc. We see very few Spaniards, because we are in Lavapiés neighborhood, the heartland of a new society, and it shows. According to Michael Ugarte 'Lavapiés provides a perfect space for ethical reflection in the wake of the real and symbolic crossing'. ${ }^{9}$ In just two minutes as indicated by Deveny: 'Colomo packs in sixty shots of immigrants from all over the world in the streets of this neighborhood as well as of strorefronts that manifest

7 Tabea Alexa Linhard, 'Between Hostility and Hospitality: Immigration in Contemporary Spain' MLN 122, 2 (2007), 400-422 (p. 404).

8 As shown by Masteson-Algar, Equatorian immigrants have been 'expelled' from central areas of Madrid thus offering a sanitized and uniform vision of the capital city. See pp. 88-122.

9 Michael Ugarte, 'Soy tú. Soy él: African Immigration and Otherness in the Spanish Collective Conscience', Studies in 20th \& 21st century literature 30 (2006), 170-189 (p. 181). 
this new world of immigrant Madrid: Cleopatra, India Style; Bisutería with half the sign in Chinese, Alimentación Bangla Town; Kurdistan Döner Kepab; Tangier Islamic Butchery (also in Arabic); and Bazra Import Export'. ${ }^{10}$ Perceptions of immigration have changed dramatically in the last few years. Not too long ago Muñoz Molina presented a very negative vision of Madrid's Puerta del Sol in his novel Los misterios de Madrid. ${ }^{11}$ This is not what happens in the case of Colomo's film, where new Spaniards are presented as part of the regular urban landscape.

Elpróximo Oriente is set as a comedy and thus the main characters are introduced in a comical way. The two brothers' names are Caín and Abel. In the opening scene Caín wears a t-shirt with an unusual writing: 'Demasiado sexo nubla la vista'. He is waiting for his online date at a Bangladeshi restaurant. While Caín is waiting, Aisha, daughter of the owners, arrives. She has already assimilated into Spanish culture and mores, has an argument with her father where she shows her perfect command of Spanish and her integration into society. Her father reacts to her being late at night in a half broken Spanish: 'Antes tu pedir permiso mi. Ser padre'. To what she reacts: "Soy mayor, soy independiente y tengo mi trabajo'. From there everything goes wrong: the restaurant is run by a Bangladeshi family and they only serve ethnic food, and of course, not beer. Caín declares to his date that he wants to have children, it turns out that she already has a six year old. The woman leaves in a hurry, shocked by the conversation and what she is offered to eat.

In the next scenes we enter the core of the film: Aisha, the daughter of the restaurant owner is pregnant from Caín's brother Abel. Through a slapstick situation, Aisha enters Caín's apartment

\footnotetext{
${ }^{10}$ Thomas G. Deveny, Migration in Contemporary Hispanic Cinema (Lanham, Maryland: The Scarecrow Press, 2012), 122-125.

11 'estaba en el centro de Madrid, en el kilometro cero, en el corazón mismo de España, y solo veía a su alrededor mendigos, tullidos, negros, marroquíes, indios de América del Sur que tocaban bombos y flautas, gente patibularia que trapicheaba en las esquinas, asesinos y salteadores en potencia'. Antonio Muñoz Molina, Los misterios de Madrid (Barcelona: Seix Barral, 1992), 28. See Rocío Peñalta Catalán, 'Dos espacios multiculturales de Madrid: Lavapiés y la Puerta del Sol' [en línea]. En: Ángulo Recto. Revista de estudios sobre la ciudad como espacio plural, 2, 2 (2010), 111-117 http://www.ucm.es/info/angulo/volumen/Volumen022/varia05.htm (consulted 18 July 2018).
} 
looking for Abel, and she throws herself off the balcony into the street. Miraculously a container saves Aisha. Her familiy assumes that Caín is responsible for getting her pregnant. Caín accepts the responsibility and he receives a crash course on Islam from Aisha's father. After a few unconventional episodes he marries Aisha. During the wedding Shakir, Aisha's father, overhears a conversation between the two brothers about the cover-up, and suffers an emotional shock.

Ana Corbalán's reading of the film suggests that it poses an inclusive dialogue between different cultures and that by representing the marginal world of Islam in Spain, establishes a contact point between two social groups considered traditionally incompatible and enables the construction of a plural identities in a not mutually exclusive way. ${ }^{12}$ This is in line with most readings of the film ${ }^{13}$, but there is one aspect that has been overlooked, the role played by food and food-related attitudes and what they mean in an increasing multicultural society.

Food eating habits are at the center of the film. In one instance, there is a conversation at the butcher's shop between Milagros, the owner, and Caín about the changing habits of their customers and how it is having an impact on their business. The conversation pictures the positive and negative aspects of Islam according to food:

CAIN: ...porque es que ya confundo a los indios de Bangladesh con los de Senegal, bueno es que ya los confundo hasta con los chinos...

MILAGROS: Mira ahí te doy la razón, si es que parece que los extranjeros somos nosotros. Si fuera por ellos además no vendería nada, ni una escoba, con eso de que no comen carne de cerdo.

$(\ldots)$

MILAGROS: ¡Pero qué dices; ¡Si el islamismo no te deja comer cerdo! ¡Con lo rico que está el jamón! ¡Si reduce el colesterol!

\footnotetext{
12 Ana Corbalán, 'Encuentros transnacionales en el cine español: Perpetuación del sujeto femenino silenciado en el Próximo Oriente'. Romance Notes 53,1 (2013), 105-115. Daniela Flesler, The Return of the Moor: Spanish Responses to Contemporary Moroccan Immigration (West Lafayette, IN: Purdue UP, 2008).

${ }^{13}$ See also Sandra Stickle Martín, Moroccan Women and Immigration in Spanish Narrative and Film (1995-2008), Doctoral Dissertation, (University of Kentucky, 2010), or the opinion of Ricard Arana Mariscal: 'defiende... olvidar la postura "nosotros-ellos" y reemplazarla por un enriquecedor "todos", La inmigracion en clave de comedia (Bilbao: Bakeaz, 2007), 40.
} 
It is a very good example of how food choices of different cultural groups are often connected to ethnic behaviors and religious beliefs. It confirms what Kittler, Sucher and Nels have pointed about the influence of food habits on an individual's self-identity as a crucial device: 'Eating is a daily reaffirmation of [one's] cultural identity'. ${ }^{14}$

While Aisha's father is recovering at the hospital, municipal police closes down the restaurant for breaking city health regulations. It is a cese cautelar. During the father's recovery, Caín convinces his in-laws (only women: mother and three daughters) to get empowered (write, learn music, sing) and also to reopen the restaurant with a few changes: allowing alcohol consumption, female waitresses, and life music. They even breach a fundamental rule of Islam in borrowing money. A friend from the savings bank where Caín's brother works comes to their subsequent financial rescue.

The transformation of their lives and their integration into Spanish culture is perceived in the changing names of the restaurant. Significantly the restaurant is renamed three times: 'Bangladesh' becomes 'Taj Masala' and finally 'Music Bar', coinciding with the evolution of the Muslim family. This last change reflects also the integration in a globalized larger Anglo-Saxon world. In the process Caín, besides becoming a husband, which was his dream at the beginning of the movie, acquires several skills, among others the ability to multitask as a father, contractor and businessman. Seeing his new Muslim family threatened with embargo because of the town hall fine and weakness of the immigrant group provoked by the father of Aisha (the patriarchal authority) being admitted to a hospital, Caín takes command of the situation and saves his new family asking for a loan to bank to finance reforms at the restaurant. As the man in charge of the family, he convenes a meeting to establish the goals of each individual and provide the funds to carry them out. He encourages Aishas' mother and sisters, Aisha, Fátima y Reemah, to engage in activities that contribute to the development of the family business based on the exploitation of exoticism and their attachment to

\footnotetext{
${ }^{14}$ Pamela G Kittler, Kathryn P. Sucher, Marcia N. Nelms, Food and culture (Belmont, CA: Wadsworth, 2012), 4.
} 
the land of origin, but also finding new motivations in life. For instance, the mother always wanted to write. She engages in a creative writing course that allows a cameo appearance by renowned Valencian writer, Juan José Millás. This teacher stresses that it is important not to mix life and fiction. One of the sisters learns to sing. Caín is empowered by assuming a patriarchal attitude that is a construct of stereotypes about male roles in both Spain and in Muslim societies. He decides what the women will do and learn. He imposes on Islamic women Spanish mores related to food, consumption of alcohol, and borrowing money. Meals and musical traditions ranks high. The subtitle of the film gives us an interesting clue: 'Una historia de amor al curry'. To solve the economic (and health) problems, with the help of Caín the Bangladeshis attempt to reform their ethnic restaurant. They fail in the effort and it ends up being a very successful musical bar to the shame of Aisha's muslim father. The customs of the country of destination -Spain- are prominent and are at the root of many clashes. As expected, the second generation has adapted to the language and customs of the host country, it has become their new habitus, and this causes a slight subversion of Shakir's patriarchal authority. He knows nothing of what happened during his long stay in the hospital, the transformation of the small restaurant into a musical bar where his daughters perform live.

A moment of crisis arises when Caín confesses to Milagros, the owner of the meat shop that things are not going well at the restaurant and that they may have to close. Milagros is facing a similar tough decision: clientele is scarce because nobody wants to buy pork products. Cristobal-Abdul shows up and advises her to start selling some halal meat. Incidentally, Deveny considers him a 'bridge character' to reduce the amount of 'Otherness' in Muslims. ${ }^{15}$ This is possible to relate to Colomo's adopted position, offering always through the movie, a position of mixing cultures without conflict as a way of adapting to new realities.

\footnotetext{
${ }^{15}$ Deveny, 123.
} 
The Peruvian band that is living at Caín's apartment is one of the weakest plot elements, but nevertheless it is useful to illustrate the clashing food cultures at play. When the musicians return to Caín's apartment he makes his brother Abel fix them dinner. It is an excellent segment to illustrate the clash between food cultures. Abel has separated from his wife in Las Palmas and has gone back to Madrid and tries to settle in his old apartment. He complains because he cannot find any pork produce in the fridge: ‘¿No hay jamón?'. Thus he cannot cook the traditional Spanish dishes he wants to, and complains because in the fridge 'no hay jamón, chorizo, cerveza...' In the end, Jorgito, the leader of the Peruvian music band, when leaving the apartment says: 'El huésped a los tres días apesta', which reminds us about some popular sayings: 'El huesped y el pez, a los tres días jié', or 'Hostes i peix menut, al cap de tres dies put'.

Caín fears that his brother will steal Aisha away from him, now that they are starting to have a good -almost romantic- relationship. When he suspects that his brother is making advances towards Aisha and that shes is not rejecting him, Caín flees the apartment and goes on a solitary walk around the city. Previously he has explained to Aisha that he once wanted to commit suicide (the image of the Viaducto de Segovia, a bridge used by suicidal people in Madrid is in point), but he was not able to do it. Instead, he should have killed his brother. At first, when he flees the apartment, Aisha thinks about him committing suicide, then she remembers that sentence and goes back to the apartment with her sisters and mother. In the meantime, Caín has returned to the apartment, he has found a ham bone on the street and is going up the stairs with the intention of killing his brother. The situation reminds the spectator of the biblical scene where according to popular belief Caín killed Abel with the jawbone of an ass. It also reminds the spectator of a famous painting by Goya Francisco de Goya's 'Duelo a garrotazos' ('Fight with Cudgels'), is a painting of the series of Black Paintings now in Museo del Prado, where we see two men in the mud trying to kill each other. Or a more recently recreation of that the scene in Bigas Luna's film, Jamón, jamón, the film that made Javier 
Bardem and Penélope Cruz famous. When Caín enters the apartment he hears the baby crying and he drops his weapon to help the child thereby strengthening his identification with his new situation as a father and husband.

Independence and emancipation through decisions is important because Caín has a subdued relationship towards Abel. The latter is the dominant, while the former (who is older) plays along. Through the evolution of the plot Caín liberates himself of Abel's dominance. It is his decision, to make things even more comical, that the name of Aisha's baby will be Adán. In a very simplistic way, but with an obvious didactic purpose, the two brothers character's take advantage of the inversion of Cain and Abel's archetypypical behavior to present opposing ideologies on immigration. Caín ends up accepting new people in the neighborhood, and Abel represents the conservative, racist stance, which sees only immigrants as cheap labor willing to be exploited by a few euros. The film is sometimes overly optimistic. In the weeding scene between Caín and Aisha intercultural dialogue becomes symbolic: it is an Islamic wedding, in a Spanish courtyard with Indian costumes, with Peruvian musicians and Muslims and Christians living together and coexisting in perfect harmony.

The hapy ending includes the victory of love, the solution of the quarrel between the two brothers, and a very kitsch final scene. The embrace between Cain and Aisha expresses very topically family togetherness which is caused by the child born to an immigrant mother and a native father. This image can be read as a statement of solidarity, a call for the transformation of the Spanish mentality, to be more open and accept intermarriage, the reality of a multicultural society with food traditions and limitations such as new regulations for food consumption. To this we should add another ending. Milagros, the owner of a butcher shop that markets meat exclusively to Spanish taste overcomes her apprehensions against immigrants that seem to be occupying the neighborhood. With the help of his new partner, Cristobal-Abdul, a Spanish convert to Islam, she tailors the butcher shop to the needs of the Muslim community and caters to their demands by placing a sign on the door 
announcing 'halal' meat prepared according to the Muslim rite. The positive result is that her business grows, and she accepts foreigners in the neighborhood. The conversion of a very traditional and unattractive typical Bangladeshi restaurant into a modern music bar and a Spanish butcher shop also shows the weight of globalization and the role that women can take in this turn. The film plays with misunderstandings generated by contacts between very different cultures. Food, religion and sex are central to the plot. Islam is the religion that is adopted by most of the Spanish characters. The latest images from the movie play with this conversion, as presented Cristo-Abdul with Cain and Aisha's father on pilgrimage to Mecca.

Deveny points to the common narrative device of the lie becoming the truth, as Aisha realizes how good a person Caín truly is, a falls in love with him. ${ }^{16}$ In a similar way, there is a Spaniard becoming a Muslim, and Bangladeshi family that is forced to accept some food rules while living in Spain. Albeit the simplistic 'buenista' neocolonialist approach in this film, it provides nevertheless food for thought, a denunciation of transformations in Spain and its difficulties. It is very different from other more recent approaches. A food show in Catalan TV3, 'Karakia' (2014) ${ }^{17}$ emphasizes ethnic cuisine at the same time that promotes cultural diversity in Catalonia. In this case immigrants have the opportunity to show how they cook thus teaching the audience about new cuisines and encouraging intercultural relations. The difference in approach may also show how attitudes in the country are changing.

\section{Food and Immigration}

Francesc Serés (Saidí, 1972) writes in his latest book, La pell de la frontera, ${ }^{18}$ about immigration in a very personal way. It is composed by fourteen pieces situated in the area where the author lived

\footnotetext{
${ }^{16}$ Deveny, 125.

17 'Karakia' http://www.ccma.cat/tv3/karakia/ (consulted 18 July 2018).

18 Francesc Serés, La pell de la frontera (Barcelona: Quaderns Crema, 2014). I will quote from this book indicating only the page number.
} 
until he was eighteen years old. The village of Saidí and surrounding areas -the Monegres, Fraga, Alcarràs, Soses, Mequinensa- are scenarios where the writer interviews some of its new inhabitants, paying special attention to immigrants that come from Mali, Senegal, Cameroon, Algeria, Morocco, Ukraine, Romania and Bulgaria. Most of them work for local farmers and live in very precarious conditions: hazardous barns and warehouses that at any time can collapse and bury them among the ruins. The author approaches working crews with a notebook and a camera. The book includes a selection of images shot by him under the unpretentious title 'Petit manual d'interiorisme i d'arquitectura efímera' (141-156). He is interested in their lives, health, livelihoods, the journey that has taken them to here from so far away. Other approaches include a dialogue with a farmer who years ago hosted an emigrant family, memories from the time when the author was teaching immigrant children in Olot, the conversation with the employee of an agricultural multinational, explanations about the book that the author makes in a writers residence in up state New York. Food is presented here in a desperate way and with a paradox. Immigrants do not have enough to eat, but they are a pivotal element that sustains the food industry at its early stages.

Serés started to write La pell de la frontera back in 2002. He incorporated autofiction, reportage and autobiography. Serés is appalled by the change he is witnessing, a destruction that borders with filthy ruins. Serés estimation of the situation is often so precise that he borders cruelty. At some point he remembers seeing in València tractors and trucks filled with oranges and vans filled with young immigrant men. He calls it the Mediterranean fireworks: cranes moving around, and up and down, buildings, "la pols sortia de les estructures de ciment $\mathrm{i}$ tot plegat semblava un castell de focs artificials'. (166) But all of a sudden he changes his mind: 'De lluny, emperò, semblava un cementiri, les làpides dels edificis a mig fer i tot de grues a sobre com si fossin les creus'. (166). This is an original way of presenting a construction bubble in the making that provokes destruction, 
appearance and disappearance, the mourning of a lost world with the concussion of a new economy. Change that creates new realities: 'L'única certesa és el canvi, que aquí esdevé desgast'. (159)

Serés deals with the unseen effects of immigration. Having migrated himself from the rural areas, being a newcomer in big or small cities, he can easily perceive the changes in rural life, not from a strictly elegiac perspective but from a much more sophisticated one. He is particularly attentive to the transformation of agriculture. All those immigrants with or without jobs have remained hidden in the Lleida area, where their help is needed to harvest, but also to do most work in the farms. In the opening piece, 'Història de les històries sense història', from the title itself he points to anonymity of the immigrant experience, to the impossibility of picturing the whole drama because they are illegal immigrants that may flee at any moment. He tells the story of Hakeem, a Moroccan teenager and his family, through the voice of an old man, Juli. He remains appalled the day Hakeem first sets foot on the farm and at one point, when Juli is not paying attention, Hakeem starts grabbing the cows fodder and flour. Juli realizes that he is so hungry that he would eat anything. He then takes this sixteen year old under his wing, works for him, and little by little his family joins him, helping Juli with the care of his bed-ridden mother. One day, all of a sudden, three sub-Saharan young men come to ask for some food. Hakeem yells at them, unleashes the dogs, and throws stones at the three men until they run away. Juli sees everything but keeps quiet. A few days later Hakeem and all his family disappear. Juli comments: 'Volien feina, això sí, com tots els que desfilen per camins i magatzems, fileres d'homes suats i bruts que quan ja no hi ha res més demanen treballar quasi només a canvi de menjar'. (29) Food is presented as a bargaining chip, or as a commodity for the survival of a human being. The impossibility of communicating because of fear and cultural differences does not help to solve the problem.

One of the highlights of the volume is the piece 'Homes entre línies'. Serés reminds the conversation he had with his friend Jordi, a food engineer, somebody that with his wide-ranging 
knowledge of new breeds can easily mock the so-called biological agriculture. He compares his situation (working in Barcelona but with bosses in London) with what happens to peach trees: 'els plantem aquí, però tota la genètica la fan els americans' (222). Serés describes the effects that food innovation has on farming land through the conversation with this well informed professional. The workmanship of this activity is performed by the contingents of Africans, that, if they are lucky, work as day laborers in the fruit fields and live in dilapidated barns next to the fields. The transformations and changes in the physical environment determines human work: the traditional lifestyles of these regions, which were those that the author had known, disintegrate at the same rate that agriculture gets technified, industrial areas (without any industries) keep growing without any company in sight, and people keep arriving without finding the job they dreamt of. There is a colonization of sorts through the import of foreign crops. Peaches are genetically modified in California (like clothing and TV series):

Hi ha una nova koiné dels gustos i dels sabors, una fruita més dolça i rodona, una fruita que anivella els consumidors que pensen que si tothom té la mateixa poma, ningú no en tindrà cap millor que la seva. El nou comunisme: si les pomes són idèntiques, el consumidor no tindrà dubtes. I, això encara és més important, si els consumidors acaben sent idèntics, les pomes no tindran dubtes a l'hora d'escollir-los a ells, com passa amb els models de cotxe, les sèries de televisió o amb la roba. És molt difícil comprar tant sense vendre's una mica cada vegada'. (222-223)

Jordi warns the narrator that all fruit grown in Lleida -the major agricultural producer area in Catalonia- are foreign types that have replaced autochthonous ones. The scenario is ready for the growth of Slow Food and a movement claiming the return of local kinds of fruit. Jordi is very attentive at the imposition of an industrialized agriculture system in recent years. He asserts that everything that does not have a regular and reliable consolidated production system will disappear. The clue is storage and conservation. In the past agriculture was based in the family system, now it is 
an industry ('la cadena de muntatge', 232) Jordi presents the laws of the land in a new kind of agriculture setting: industry and anonymity against family traditions.

Jordi also talks about the first domestic animal: the goat, an animal that offers many advantages, among others it is a 'migrant' animal, easily transferable, that could be used in many ways: protein factory, meat and milk, and finally they become a coat (233). He denounces how agriculture has become an international business ruled by US industries with transgenic solutions:

¿Saps la de varietats que s'han extingit per culpa de les millores genètiques? En gairebé totes les cadenes de distribució demanen les mateixes pomes. Estàndards, és clar. Granny Smith perquè té la pell diferent, Royal Gala, Fuji, Golden i una altra de vermella, la Top Red i l'Early Red One... (241)

The last two pieces in the book, 'Els àngels que riuen' and 'La fi del món tal com l'havíem conegut', have a characteristic Serés texture: he relates major social upheavals, dramatic changes to little events, changes in nature, mechanization of agriculture, in a metaphorical way. In 'Els àngels que riuen', he refers as he does through the book to the changed nature of landscape around his hometown: 'Hi ha un paisatge de frontera que va des de la carretera de Tamarit fins al costat de l'A2 entre Lleida i fins que s'arriba als Monegres, zones àrides i plantacions que s'acaben o comencen en benzineres, polígons industrials més o menys actius, serres àrides, erms' (283). He introduces a landscape after a battle, abandoned by its owners, now that the economic crisis is at its height, he runs into a couple of immigrants, one of them is going through an acute food allergic reaction after eating a can of sardines. This allows the author to muse about his own miseries with food allergies, since before being born. He helps the two immigrants. He arrives to secured fields, lines of peach trees protected with nets from birds and hail (292). The fear of hail is compared to social and economical upheaval: 'Parlo d'ara i d'aquí, de Saidí a Alcarràs, però també d'un present ubic i contemporani durant el qual hem mirat de teixir mil xarxes de seguretat per tal de conjurar el futur, en una mena de cel social, però la veritat és que els déus són grecs i no hi ha res previst' (293). Serés 
discusses the disappearance of what many in Spain perceived as guaranteed social pillars of education, health and safety. The crisis - a metaphorical hail- has gotten rid of everything, and there is no safety net available. Serés critique underscores the impact of anonymous immigrants in food production and the colonization of local crops, thus showing the dark side of multiculturalism and globalization.

Throughout the book the author is genuinely concerned about the nature and the sense of what he is writing. He declares towards the end that trying to write about immigration is intentar descriure un núvol' (304). Or that he is mesmerized by the little importance that the subject has, similar to constructing just a list: 'No em queda res més per dir, d'aquí, mentre vaig escrivint m'adono que relato un inventari, res'. (305). This idea of little importance, of smallness, the narrator repeats again and again (108). Serés has seen this landscape being transformed without almost perceiving it. While attending a writer's colony in Upstate New York he presents his idea of his book to a few fellow writers and a publisher in a very candid way: 'Escric una mena d'història local, no sé ben bé com definir el llibre que escric' (54). A publisher in the group suggests that he should try a love story, include love letters. Serés is reluctant to write a love novel, or to write about the Holocaust, or even a historical novel. He keeps being mesmerized by the stories he keeps hearing that are always the same (54). He also uses military terms: the place where imigrants live is like a 'trinxera', a trench in the middle of the war line. In fact, Serés is unaware of the insurmountable task he has started, the difficulty of writing a book and finding the common traits between all these little life plots he encounters and keeps writing about:

Vida quotidiana i repetida al pati de baix; de tan petita, quasi invisibles, passes per davant $\mathrm{i}$ tot es torna borrós de tan clar com sembla. ¿Com es narra això? Els bolígrafs es gasten, les llibretes arriben a la darrera pàgina i la vida continua'. (257) 
The narrator acknowledges that he is dealing with the unseen, something that it is not perceived, with a variable of what Georges Perec called the infraordinaire as opposed to extraordinaire. ${ }^{19}$ Here we are also dealing with an unconscious refusal to see. One of the limitations when exploring the everyday is the difficulty to see what it is so obvious. In this case, most observers refuse to see through racial and social stereotypes: 'Sóc un estrany, de vegades només cal desplaçar-se uns mi·límetres del centre per caure als antípodes' (57). Serés is in a place with no dignity, no glamour, in a desert land between Aragón and Catalonia, near the Monegres area. He tries to discover his own place and that immigrants in this desert.

As indicated, Serés is plagued with many doubts about the sense of his book that he shares with the reader. In the final two pages he links these narratives to some of his previous writing: els pitjors pronòstics que es llegeixen entre les línies de La força de la gravetat i de La matèria primera s'han complert. No és que s'hagin convertit en realitat, ja hi eren mentre als mitjans es descrivia una aparença de prosperitat, hi havia un tel tan fi com opac que pocs s'atrevien a esquinçar. Tot era de paper, només calia bufar una mica perquè comencés la pitjor crisi econòmica que es recorda I que ens marcarà a tots per molts anys. (307)

These are striking words that tackle the heart of the immigration problem in Spain's recent history. The transformation of the country through contrasting cultures, cheap labor that jumped into the construction bubble, the illusion of prosperity created by politicians and bankers alike, a sinister coalition that has devastated Spain. Serés is keen in using subtle metaphors to refer to the everyday: 'un tel tan fi com opac que pocs s'atrevien a esquinçar', meaning by this the collective refusal, to see what was happening before their eyes. In La pell de la frontera he focuses on immigrants, in a journalistic way, literally interviewing hundreds of them, getting to know their intimate journeys though anonymous stories. He even -as on many occasions in his narrative- refers in a selfreferential way to what he is writing: 'El temps s'ha accelerat: la crisi ha estat fulgurant, la immigració

${ }^{19}$ Georges Perec, L'Infra-ordinaire (Paris: Seuil, 1989). 
ha modificat el mapa del país i la situació política ho canvia tot. Fins i tot als llocs que ofereixen més resistència: la plaça José Antonio es diu Joaquim Ibarz i el bar que hi havia està tancat' (307). He sees some signs of hope through the timid renovation of historical memory, dedicating a square in Saidí to a journalist born there (Serés' hometown) a correspondent in Latin America for La Vanguardia, erasing the name and memory of the infamous founder of Falange, Spain's most prominent fascist party.

Serés links the immigrant's situation and experiences with 'la independència, el tema dels temes'. (307) It is 11 September, Catalonia's national day, and Serés is trying to explain Catalonia's claim for independence to a group of immigrants in Lleida, who have seen many flags and cannot make sense of it. One of the immigrants has the right questions: When will this happen? Isn't it too dangerous? Asks the immigrant. Serés is surprised, because the kind of dangers that those immigrants have faced just to get to Spain are tremendous:

¿Crisi? ¿Risc? No sé com respondre a algú que s’ha jugat la pell com ho ha fet ell, algú que després de travessar cinc països ha saltat a l'Atlàntic en una barca per arribar a les Canàries i que ha anat de ciutat en ciutat fins a arribar a Lleida per acabar dormint al ras i treballar a la fruita. Tot plegat sense garanties, sense salvavides. (308)

These anonymous workers have been the pillar of the renovation in agricultural activities in Catalonia and Spain. By relating these pressing issues: the crisis, immigration and Catalonia's claim for independence, Serés is linking three of the most urgent problems Spain is facing as a collective quagmire. Similarly to what happened in 1898, when it lost its last colonies, no one in the country seems willing to acknowledge the gravity of the situation.

La pell de la frontera shows the struggle for survival of people who came from afar to do the jobs that unemployed natives do not want to do anymore, and suggests the permeability of the border that separates us from the other. The author walks through inhospitable areas armed with his pen and block, and immigrants believe he is a policeman. Serés' book presents the toughest aspect of 
immigration: the fruit pickers, men working in the poultry and pig farms of Segrià. At the end of the book he discusses how immigrants have settled down with a minimum of adaptation to the environment. Serés with acute sensitivity has revealed the melting pot of the meeting point for immigration and the country's population, revealing that the border is no longer in the Strait of Gibraltar or the island of Lampedusa (Italy) or of Lesbos (Greece), but in our streets and fields, villages and cities within us, in an invisible symbiosis.

\section{Francesc Serés' Lost World}

Francesc Serés is a -relatively- young writer with a very original career in the Catalan literary field. With his trilogy De fems $i$ de marbres, he became the youngest author ever to receive the National Prize for Literature in 2007. After this trilogy of novels he published two sets of short texts that continued to explore the territory and the world of work, halfway between literature and ethnography: La força de la gravetat and La matèria primera. In his following three books he performed a twist: Caure amunt is theatrical recreation of the life of three medieval Catalan authors; Contes rusos is a metafictional tour de force; and the short stories in Mossegar la poma focuse on married life.

As indicated by Jordi Marrugat in a recent book ${ }^{20}$, he followed the example of Jesús Moncada and Maria Barbal, writing a critical representation of a rural world in a very original way. Francesc Serés became an innovative narrator, similarly to Moncada, who was born in the Franja de Ponent. His trilogy was also based on the observation of changes in lifestyles and habits that occurred so rapidly in modernity and postmodernity. In fact, in a text written in tribute to Moncada, he stressed that Moncada's great feat was to allow, thanks to literature, the survival of Mequinensa, and town that was buried under water at the mercy of francoist policy of building damps. Speaking of Moncada Serés highlighted that in his books one can perceive 'l'imaginari col·lectiu' of the old town. And he added:

${ }^{20}$ Jordi Marrugat, Narrativa catalana de la postmodernitat. Històries, formes $i$ motius (Barcelona: Publicacions i Edicions de la Universitat de Barcelona, 2014), 171-174. 
Una de les tasques de l'escriptor és mostrar el que els altres saben mirar però no saben veure ni llegir. Moncada situa al plànol tot allò que ja no és, el riu, els masos i. encara més, el poble, la descripció de les vides de veïns, avantpassats, enemics i familiars diversos. 21

Serés's trilogy is constructed as a narrative based on small episodes, stories seemingly unconnected to each other the protagonist of which is 'ningú, el viure dels qui som ningú', ${ }^{22}$ the anonymous lives of those who are forgotten by history's main narrative, but which are the basis of it and suffer the ups and downs of history. This anonymous collective biography covers crucial times in a region west of Lleida, covering issues such as depopulation of the countryside, and misery of city life for those just arrived from small towns, including references to the Spanish immigration Barcelona to the sixties. ${ }^{23}$ This was an epochal transformation of a particular landscape that Hobsbawm has described with acute precision. ${ }^{24}$

In his trilogy, because of his attention to the hidden everyday ('el que passa és que res no passa'), ${ }^{25}$ he included remarkable comments on food and related topics:

L'hora de dinar es coneixia aviat, les flaires dels sofregits o del brou de gallina pujaven puntualment pel buit de les escales, també la dels esquitxos de l'oli i la carn de corder (...) ara els menjadors separats de les cuines no s'olora res, no arriba més que el sòlid o el líquid del menjar, les cases ja no fan olor de cuina.26

Here he depicts the separation of two crucial spaces that in the past, in rural living were lived as one: kitchen and dining room. Or he also shows the significance of weekly town markets that he considers to be the center of the world:

\footnotetext{
${ }^{21}$ Francesc Serés, 'Pilans i parets mestres’ El país. Quadern (16 junio 2005), 2.
}

22 Francesc Serés, De fems i de marbre (Barcelona: Quaderns Crema, 2007), 50.

${ }^{23}$ According to Marrugat, the formula of this narrative trilogy -a recovery of a disappeared world from the consciousness of the individual and collective changes that have taken place- is similar to that of Spanish writer Julio Llamazares. In his second novel, La llwia amarilla (1988), Llamazares tells the depopulation of a village in the Aragonese Pyrenees. And in Escenas de cine mudo (1994) he shares with De fems i de marbre the use of photographs as activators of past gone memories.

${ }^{24}$ Eric Hobsbawm, The Age of Extremes: The Short Twentieth Century, 1914-1991 (New York: Vintage Books, 1994).

${ }^{25}$ F. Serés, De fems..., 49.

${ }^{26}$ F. Serés, De fems..., 80. 
No hi ha cap altre lloc al món com el mercat, no n’hi ha cap altre perquè el món només té un centre, i el centre és un mercat curull de gent que es mou i es crida.

(...)

escoltar els crits del xai que mataven en una parada a la vista de tothom i que en un tres i no res veies en forma de costelles tallades, de cuixa feta a talls, i el cap espellotat, preparat per anar al forn; dinar de diumenge, un cap per cap, festa. Festa de xai, de conills, de porcs. El mercat sempre ha estat el lloc de la festa i del sacrifici. ${ }^{27}$

These two quotes reveal an elegiac view of eating habits and the food production chain in a (pre)industrial mono-ethnic world. All this has disappeared and the crisis is the perfect storm that made it happen.

In the short stories of La força de la gravetat, Serés also shows very meticulous attention to tiny aspects of everyday life: offices and factories; presence of evil and sinister coincidences; lives in the margins of a post-industrial society, such as a seller of perfumes, guards in a container storage area, workers in foundries and in an industrial bakery. There are references to food and the impact on the life and imagination of the people: 'El preu' focuses on the importance of hunting and fishing. The narrator's grandfather cannot enter a restaurant because he is not properly dressed. He goes to buy a formal suit and returns to the restaurant, and once seated at the table, after ordering, he throws the table to the ground and leaves the restaurant without uttering a word. These are seventeen stories with extremely minimalist plots carved with precise words, sharp and with obvious referents, in rural or urban suburbs, that picture 'la perifèria moral de les vides subalternes'. ${ }^{28}$ In this he describes microclimates of Catalonia in recent decades, with its rituals, its rules and shapes.

\section{Food, Migrations. A Multicultural Spain?}

As I have shown here, food and immigration are an important aspect of cultural studies. The new space of colonial contact, this time in the metropolis, somehow resurfaces (and is developed)

${ }^{27}$ F. Serés, De fems..., 171, 173-174. See also 'l'abandó progressiu de les terres' (244); a Sunday's big meal with an open table 'com si fos un llibre amb un faristol a sota' (253).

${ }^{28}$ Manel Ollé, 'Societat anònima', Avui Cultura, (5 d'abril 2006), 13. 
through daily eating habits and experiences, with an impact on dialogue: agreement or disagreement, shock or rejection, a clash of cultures that provoke new unexpected situations. Paying attention to this aspect of the colonial experience, we can better understand the transformation of Spanish society of the twentieth and twenty-first century. Henri Lefèbvre wrote that everyday life, in a sense residual, [is] defined by 'what is left over.' ${ }^{\text {'9 }}$ Lefèbvre viewed the everyday as the total of all lived experience of the ordinary, the recurrent: daily routes, tasks, work, and commuting to the workplace as well as vacation, funerals, the weekly visit to the cinema or dance hall, "hobbies," family visits, and so on. That which he names as "what is left over" does not constitute a definition; first and foremost, it instead negatively describes everything that does not count in life as special or unique. It is an everyday marked by hybridity. According to Cornejo-Parriego hybridity 'constituye un fenómeno infinitamente diferido no sólo por ser un proceso abierto y progresivo, sino también por la mezcla que se produce con y entre colectivos en si mismos mestizos que impiden llegar a una noción estable y pura de cualquier denominación racial'. ${ }^{30}$ Immigration is provoking many changes in Spanish society as a whole. It is also testing the limits of accepting multicultural situations. The farther we are from the big city, the easiest it is to get lost and disappear, and to accept the cruelity of a situation that affects the very core of the food industry: productions and consumption. Serés amply exemplifies this issue which could be linked to one aspect not developed here, what Krishnendu Ray calls the uneven relationship between 'subordinate ethnic other and the self that focuses on consumers and their desires. He calls attention to the paradox that a central discussion in food studies should be around the stories and subjectivity of the 'ethnic food provider'. ${ }^{31}$ In developed countries, 'although the foreign-born have numerically dominated the feeding occupations [...], we know

\footnotetext{
${ }^{29}$ Henri Lefèbvre, Critique of Everyday Life Vol. 1 (London: Verso, 1991), 97.

${ }^{30}$ Rosalia Cornejo-Parriego, 'Espacios híbridos, iconos mestizos: imaginando la global', Letras Peninsulares 12, 2-3 (1999-2000), 255-275 (p. 526).

${ }^{31}$ Ray, 1.
} 
relatively little about how the transaction in taste appears from their point of view'. ${ }^{32}$ Ray stresses the need to incorporate 'immigrant bodies and conceptions into (...) discussions of taste' because it is the only way to understand that migrants have the resources 'to turn the table on the dominant culture of taste'33

In cultural terms, in essence, what one eats defines what one is and is not. An important element in this type of research is how food and eating habits contribute to the development and transmission of culture. Culture is defined as beliefs, values, attitudes and practices and accepted by members of a group or community. Culture is not inherited; it is learned. The food options from different cultural groups are often connected to ethnic behavior and religious beliefs. In this article I have detected two problems: the cultural shock caused by differences in eating habits because of cultural and religious reasons; and the involvement of immigrants in the transformation of the agricultural production process and what people eat. Mass immigration since the nineties has meant the need to create new opportunities for communication and coexistence. A moment of great transformation occurs because of this migration's impact.

If the scarcity of the years of war and dictatorship produced discourses about the need for sacrifice and duty of the citizen affecting both the public and private spheres, recent immigration points to food and what it represents as an engine of social change. Eating practices, traditional foods, ingredients and new products begin to form part of a new horizon of everyday expectations. The new space of colonial contact, this time in the metropolis, reemerges (and gets new forms) through daily eating experiences. At this point of encounter and misunderstanding, shock or rejection, the colonial experience is a new field of cultural and literary analysis that helps us better understand the transformation of Spanish society of the twentieth and twenty-first century.

\footnotetext{
32 Ray, 15.

${ }^{33}$ Ray, 194.
} 